\title{
PENENTUAN HARGA POKOK PRODUK UBI CINCANG PEDAS PADA USAHA "AISAH" DESA SANTONG KABUPATEN LOMBOK UTARA
}

\author{
Lukman Effendy ${ }^{1}$, Zuhrotul Isnaini ${ }^{2}$, Isnawati ${ }^{3}$ \\ Fakultas Ekonomi dan Bisnis Universitas Mataram \\ lukman.effendy@unram.ac.id ${ }^{2}$
}

\begin{abstract}
ABSTRAK
Setiap usaha harus memperhitungkan dengan tepat harga pokok produk atau jasa yang ditawarkannya. Pada saat perhitungan harga pokok produk tidak tepat, dalam hal ini terlalu murah atau kurang dari seharusnya, maka akan menyebabkan kesalahan suatu usaha dalam menentukan harga jual produk atau jasa. Usaha "Aisah" adalah salah satu jenis usaha rumahan yang punya potensi besar untuk berkembang karena keunggulan rasa keripiknya yang enak dengan bumbu khas, seharusnya memperhitungankan harga pokok produk dengan akurat. Sudah tepatkah harga pokok yang ditetapkan oleh Usaha "Aisah" untuk produknya? Sudah tepatkah harga jual Produk Ubi Cincang Pedasnya?

Maka kegiatan pengabdian ini menjadi urgent dilakukan sebagai solusi untuk permasalahan tersebut. Adapun jenis kegiatan pengabdian ini adalah membantu usaha "Aisah" untuk menentukan harga pokok produknya. Target luaran yang diharapkan dari kegiatan ini adalah publikasi hasil kegiatan pengabdian berupa artikel pada salah satu media masa di Nusa Tenggara Barat (NTB) atau Publikasi di Jurnal Pengabdian Pada Masyarakat yang ada di Indonesia. Metode Pelaksanaan kegiatan pengabdian ini dilakukan dengan metode pendampingan dalam penghitungan harga pokok produk, dan nantinya pemilik usaha akan dilatih untuk menghitung harga produk tersebut.
\end{abstract}

Kata Kunci: Harga Pokok Produksi, Penetapan Harga Jual 


\section{PENDAHULUAN}

Menurut UU no. 5 Tahun 1984, industri adalah kegiatan ekonomi mengolah bahan mentah, barang baku, barang setengah jadi dan atau barang jadi menjadi barang dengan nilai yang lebih tinggi penggunaanya, termasuk kegiatan rancang bangun dan perekayasaan industri. Undangundang nomor 3 tahun 2014 tentang perindustrian, menjelaskan tentang industri adalah bagian penting bagi masyarakat karena dapat memajukan dan membentuk seluruh kegiatan ekonomi rakyat, industry juga bisa dikategorikan dari bebagai macam seperti industry hijau, industry perumahan, industry srategis dan lain sebagainya. Bahan-bahan industri diambil secara langsung maupun tidak langsung, kemudian diolah, sehingga menghasilkan barang yang bernilai lebih dan memiliki nilai guna bagi masyarakat. Kegiatan proses produksi dalam industri itu disebut dengan perindustrian. Salah satu contohnya adalah industri olahan singkong.

Industri olahan singkong yang sebagian besar dilaksanakan oleh petani berperan dalam penyerapan tenaga kerja dan penanggulangan kemiskinan salah satu industri kecil-menengah yang mampu menyerap sejumlah tenaga kerja. Peluang Industri makanan olahan singkong ini sangat baik. Berbagai riset dan inovasi menuju diversifikasi produk pangan olahan yang menggunakan singkong sebagai bahan baku utama telah dilakukan.

Perkembangan industri olahan singkong, selalu dihadapkan dengan permasalahan yang menyangkut bahan baku yaitu kedelai, ketersediaan dan kualitas faktor produksi, tingkat keuntungan, pemasaran serta permodalan. Laba dari industri olahan singkong sangat tergantung dari penjualan dan biaya-biaya produksi yang dikeluarkan. Industri ini akan bertahan hidup serta berkembang apabila mampu mengelola biaya secara efektif dan efisien, demi meraih laba maksimal. Apabila sebuah perusahaan tidak dapat mengelola biaya secara baik, maka laba atau keuntungan pada perusahaan tersebut akan sulit dicapai, bahkan dapat mengakibatkan kerugian. 


\section{Jurnal ABDIMAS INDEPENDEN}

Vol. 2, No. 2, November 2021

Masalah lain dari industri olahan singkong adalah keterbatasan bahan baku singkong. Hal yang sama dihadapi oleh Pak Heri Sagruk sebagai pemilik Usaha "Aisah". Keterbatasan bahan baku menyebabkan harga bahan baku singkong berfluktuasi, sehingga menyulitkan dalam menghitung harga pokok produk. Selama ini, perhitungan biaya produksi yang dilakukan oleh Usaha "Aisah" hanya berdasarkan perkiraan saja. Usaha "Aisah" hanya menghitung biaya produksi berdasarkan bahan baku saja tanpa menghitung biaya seperti penyusutan, gaji karyawan, dan biaya overhead pabrik. Hal ini dapat mempengaruhi keuntungan yang didapat dan dapat membuat usaha mengalami kerugian.

Oleh sebab itu suatu usaha harus melakukan perhitungan harga pokok produksi secara tepat. Agar produksi yang dihasilkan dapat dijual dengan harga yang bersaing dan dengan kualitas yang bersaing juga.

\section{Permasalahan}

Masalah pokok yang sering terjadi dari para pengusaha industri olahan singkong adalah kesulitan dalam perhitungan biaya produksi akibat naik turunnya harga bahan baku. Usaha "Aisah" menentukan harga pokok produk hanya berdasarkan perkiraan saja. Usaha "Aisah" hanya menghitung biaya produksi berdasarkan bahan baku saja tanpa menghitung biaya seperti penyusutan, gaji karyawan, dan biaya overhead pabrik. Hal ini dapat mempengaruhi keuntungan yang didapat oleh perusahaan dan dapat membuat perusahaan mengalami kerugian.

\section{SOLUSI DAN TARGET LUARAN}

Berdasarkan uraian pada latar belakang dan permasalahan yang dijelaskan di atas, maka kegiatan pengabdian kepada masyarakat ini menawarkan solusi untuk masalah perhitungan harga pokok produksi yang dihadapi oleh Pak Heri Sagruk sebagai Pemilik Usaha "Aisah" di Santong, dengan cara memberikan pendampingan dan pelatihan cara menghitung 
harga pokok produksi yang sesuai menggunakan pendekatan Full Costing. Harapannya dari kegiatan PKM ini, Pak Heri Sagruk benar-benar menentukan harga jual berdasarkan harga pokok produksi yang sudah dihitung sebelumnya. Hasil dari kegiatan pengabdian ini akan dipublikasikan pada salah satu Jurnal Pengabdian Kepada Masyarakat. Publikasi ini menjadi target luaran dari kegiatan PKM ini.

\section{METODE PELAKSANAAN}

Pendekatan/metode pelaksanaan kegiatan pengabdian ini dilakukan dengan metode pelatihan dan pendampingan dalam menghitung harga pokok produksi dengan pendekatan Full Costing.

\section{HASIL DAN PEMBAHASAN}

\section{Gambaran Umum Usaha "AISAH” Desa Santong KLU}

Kegiatan pengabdian pada masyarakat ini telah dilaksanakan di Usaha Ubi Cincang Pedas "AISAH" di Kabupaten Lombok Utara. Pemilihan ini lokasi di Lombok Utara ini adalah mengingat pentingnya sharing ilmu dalam hal pengelolaan usaha, dalam hal ini adalah dalam penentuan harga pokok produk yang dihasilkan oleh Usaha "Aisah".

\section{Gambaran Umum Ilmu Pengetahuan dan Teknologi (IPTEK)}

\section{Harga Pokok Produksi}

Menurut Mulyadi (2005:14), biaya produksi merupakan biaya-biaya yang dikeluarkan dalam pengolahan bahan baku menjadi produk. Suatu perusahaan perlu menentukan harga pokok produk yang dihasilkan karena harga pokok merupakan salah satu yang dijadikan sebagai pertimbangan dalam menentukan harga jual produk, serta kebijakan lainnya dalam pengelolaan perusahaan.

\section{Tujuan Perhitungan Harga Pokok Produk}

Tujuan dari perhitungan harga pokok produksi adalah sebagai berikut: 
1. Sebagai salah satu faktor yang harus dipertimbangkan dalam penentuan harga juat produk didasarkan pada biaya produksi ditambahkan biaya lain yang telah dikeluarkan dan laba yang diinginkan.

2. Sebagai salah satu faktor yang harus dipertimbangkan dalam penentuan biaya produk untuk produk baru dan pesanan khusus.

3. Untuk penentu kebijakan penjualan.

\section{Unsur-unsur Biaya Penentu Harga Pokok Produksi}

Menurut Witjaksono (2006), biaya-biaya dalam penentuan harga pokok produksi terdiri dari tiga unsur, yaitu:

a. Biaya Bahan Baku (Direct Material)

b. Biaya Tenaga Kerja Langsung (Direct Labour)

c. Biaya Overhead Pabrik (BOP)

\section{Pendekatan penentuan harga pokok produksi}

Menurut Mulyadi (2015:18) dalam memperhitungkan unsur-unsur biaya ke dalam harga pokok produksi, terdapat dua (2) pendekatan yaitu:

1. Full Costing, merupakan metode penentuan harga pokok produksi yang memperhitungkan semua unsur biaya produksi ke dalam harga pokok produksi, yang terdiri dari biaya bahan baku, biaya tenaga kerja langsung dan biaya overhead pabrik, baik yang berperilaku variabel maupun yang berperilaku tetap.

2. Variabel Costing, yaitu metode penentuan harga pokok produksi yang hanya membebankan biaya-biaya produksi saja ke dalam harga pokok produk, yang terdiri dari biaya bahan baku, biaya tenaga kerja langsung serta biaya overhead pabrik yang berperilaku variabel saja. 


\section{Proses Produksi Ubi Cincang Pedas}

Gambar 1. Produk Jadi Ubi Cincang Pedas

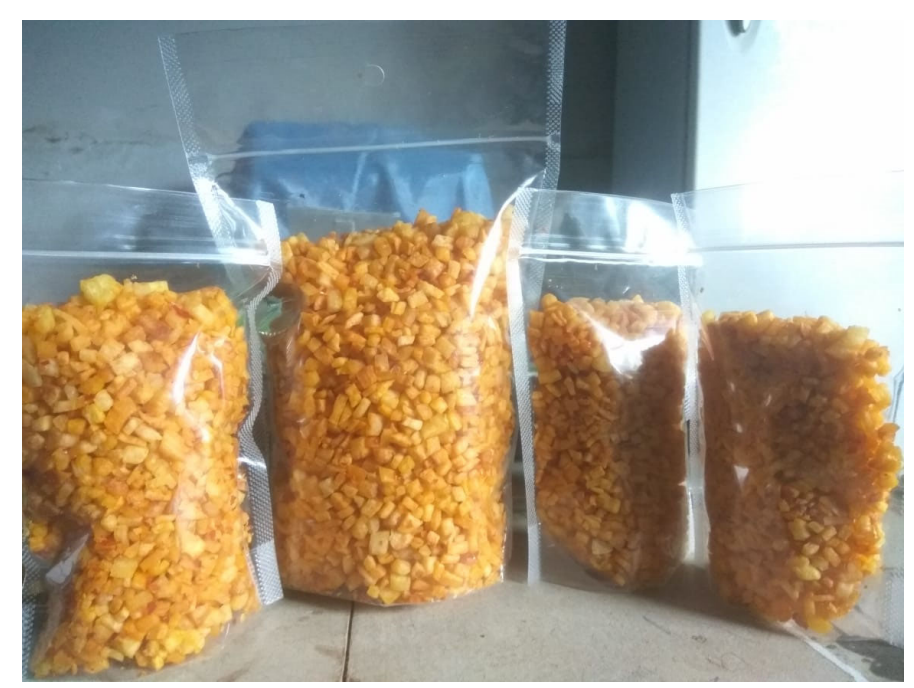

Sumber: Usaha Aisah

Ubi cincang pedas adalah makanan yang dibuat dengan bahan dasar ubi yang dipotong-potong berbentuk dadu kecil, diberikan bumbu sehingga terasa pedas di lidah. Produk ini adalah merupakan salah satu produk unggulan dari Usaha Aisah, selain produk keripik singkong. Ubi cincang pedas ini sebenarnya adalah camilan khas santri pondok pesantren di Kediri, Lombok Barat. Istri dari pemilik, atau Bu Heri Sagruk adalah seorang alumni pondok pesantren di Kediri Lombok Barat. Bermaksud hendak nostalgia mengingat masa-masa di pondok, Beliau mencoba untuk membuat camilan semasa di pondok, yang ternyata malah dapat diproduksi dan dipasarkan lebih banyak di Desa Santong Kabupaten Lombok Utara.

Berikut ini adalah proses pembuatan Ubi Cincang Pedas ini secara singkat:

1. Siapkan ubi kayu yang akan digunakan sebagai bahan pokok dari ubi cincang pedas.

2. Ubi tersebut dikupas kulitnya, kemudian dicuci bersih.

3. Setelah ditiriskan, ubi yang telah dikupas, dicincang kecil-kecil. Tahapan ini yang membutuhkan waktu paling lama dalam proses produksi. 1 
karung ubi, bisa menghabiskan waktu hingga 3 sampai dengan 5 hari untuk dapat dicincang secara keseluruhan.

4. Ubi yang telah dicincang kecil-kecil tersebut kemudian digoreng, dan ditiriskan.

5. Ubi cincang yang telah matang, dimasukkan ke dalam wadah mangkuk plastik besar, kemudian dituangi azbumbu, kemudian diaduk, agar bumbu pedas tersebut merata di seluruh ubi cincang yang ada.

6. Ubi cincang pedas tersebut kemudian dikemas ke dalam berbagai kemasan. Kemasan yang digunakan umumnya adalah kemasan kecil, sementara kemasan ukuran besar hanya berdasarkan pesanan.

\section{HASIL DAN PEMBAHASAN}

Hasil

Usaha pembuatan ubi cincang pedas dari Usaha Aisah telah dirintis sejak 5 tahun yang lalu. Produksi usaha aisah adalah kacang asin, produksi keripik singkong, dan keripik cincang pedas. Varian produk ini secara rutin diproduksi oleh Usaha Aisah, untuk memenuhi permintaan secara lokal di wilayah Santong dan Kayangan. Selain itu, Usaha Aisah juga menerima pesanan-pesanan khusus untuk varian produk yang sama, namun dengan kemasan yang berbeda.

Bapak Heri Sagruk sebagai pemilik dari Usaha Aisah tidak menggunakan pendekatan apapun untuk menghitung harga pokok produk yang sesuai dengan kaidah akuntansi biaya dan tidak mempertimbangkan biaya produksi secara detail. Tentunya praktik ini tidak dapat dibenarkan, karena bisa jadi terdapat kesalahan dalam penentuan harga jual. Untuk menghindari terjadinya kesalahan dalam perhitungan biaya produksi dan agar menghasilkan efisiensi biaya diperlukan suatu metode yang baik dan tepat. Metode yang dapat dipergunakan dalam perhitungan biaya produksi tersebut adalah metode full costing dan variable costing. Metode-metode tersebut belum tentu diterapkan pada usaha-usaha kecil dan menengah 
seperti Usaha Aisah, sehingga penerapan metode perhitungan harga pokok tersebut perlu diperkenalkan melalui kegiatan pengabdian kepada masyakat. Dalam hal ini penggunaan metode full costing untuk menghitung harga pokok produk ubi cincang pedas Usaha Aisah.

Kegiatan pengabdian dilaksanakan pada Tangga I0 Oktober 2020 yang dimulai dari pukul 09.00 WITA sampai dengan selesai. Kegiatan pengabdian dilaksanakan dengan metode diskusi dua arah, dan berikut adalah rincian kegiatan pengabdian yang dilaksanakan:

1. Diskusi awal

Diskusi awal dilakukan antara tim pengabdian dengan Bapak Heri Sagruk untuk mengumpulkan data-data awal dan untuk mengetahui proses produksi dari Ubi Cincang Pedas yang selama ini dilakukan. Kegiatan ini bertujuan untuk menganalisis biaya-biaya produksi yang muncul dari proses produksi ubi cincang pedas. Berikut adalah data produksi Ubi Cincang pedas setiap kali produksi dilakukan (membutuhkan waktu 4 hari) berdasarkan penjelasan dari Bapak Eri Sagruk:

Tabel 1: Identifikasi Biaya Produksi per Bulan berdasarkan Wawancara

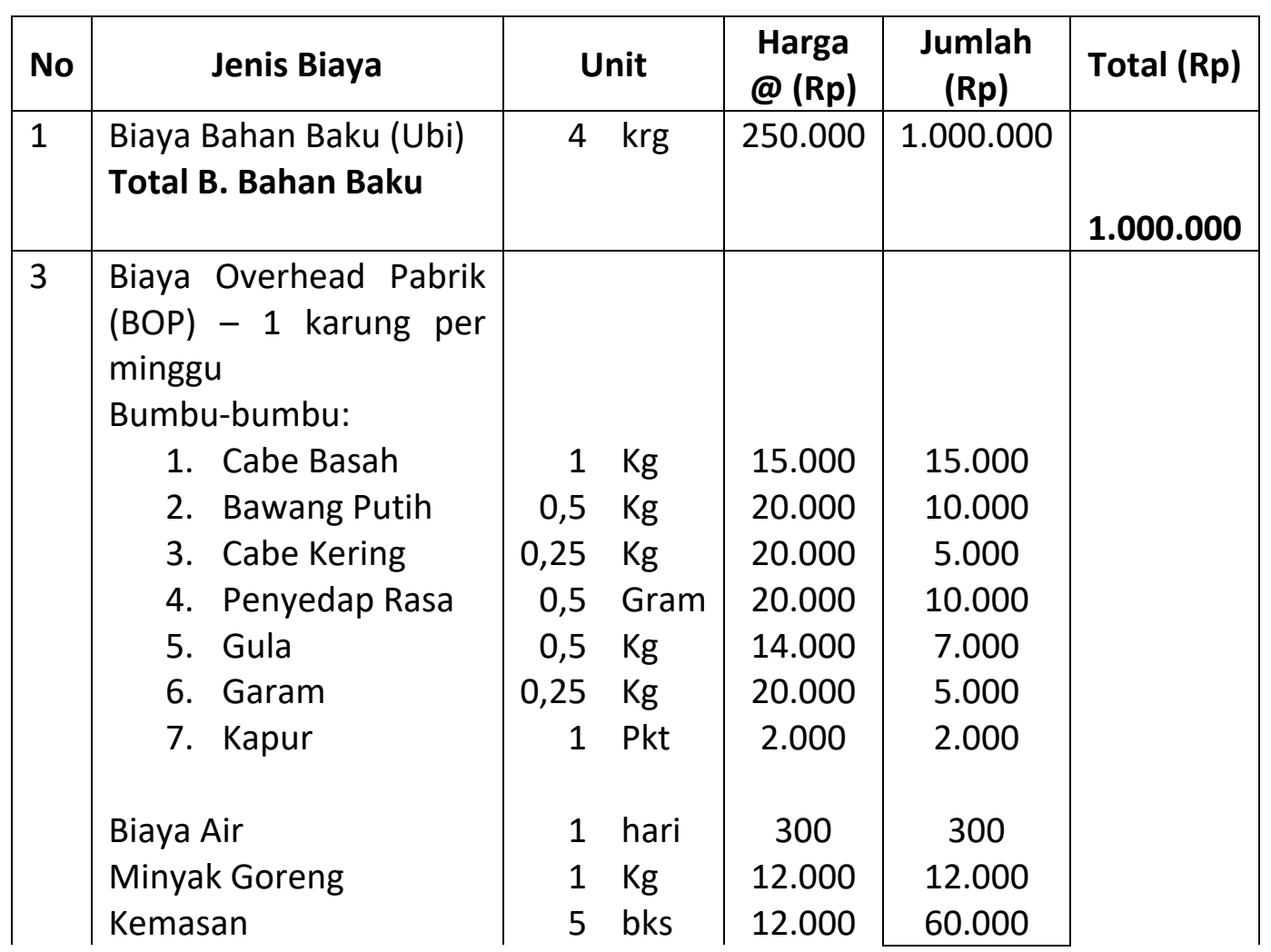




\section{Jurnal ABDIMAS INDEPENDEN}

Vol. 2, No. 2, November 2021

\begin{tabular}{|l|l|l|l|r|r|}
\hline No & \multicolumn{1}{|c|}{ Jenis Biaya } & Unit & $\begin{array}{c}\text { Harga } \\
\text { @ (Rp) }\end{array}$ & $\begin{array}{c}\text { Jumlah } \\
(\mathbf{R p})\end{array}$ & Total (Rp) \\
\hline & $\begin{array}{l}\text { Total BOP per bulan } \\
\text { Harga Pokok Produksi }\end{array}$ & & & 126.300 & \\
& HPP/Unit & & & & $\begin{array}{r}505.200 \\
1.505 .200 \\
\text { Rp 752.6 }\end{array}$ \\
\hline
\end{tabular}

Sumber: Data Primer (diolah)

Keterangan:

a. Biaya tenaga kerja langsung yang digunakan selama proses produksi tidak dipertimbangkan sebagai biaya dalam proses produksi. Hal ini disebabkan dengan pertimbangan bahwa tenaga kerja yang digunakan adalah tenaga sendiri, tenaga tetangga yang sukarela datang membantu, sehingga tidak perlu diperhitungkan dalam perhitungan biaya.

b. Biaya air per bulan adalah sekitar Rp 10.000. Biaya ini cukup murah, dikarenakan air yang dipergunakan adalah air yang pengelolaannya oleh BUMDES. Di dalam proses produksinya, Ubi Cincang Pedas membutuhkan hanya dalam 1 hari, dari 4 hari proses produksi. Untuk memudahkan perhitungan dan jumlahnya yang tidak material, maka biaya per hari untuk biaya air diasumsikan Rp 300.

c. Peralatan yang dipergunakan maupun aset tetap lainnya tidak menggunakan metode penyusutan atau penurunan nilai apa pun. Bapak Eri Sagruk bahkan tidak mengetahui akan perlunya penyusutan atas penggunaan peralatan maupun aset tetap lainnya yang dipergunakan dalam proses produksi.

d. Proses produksi yang dilakukan tidak setiap hari, melainkan untuk memenuhi ketersediaan stock pada warung-warung sekitaran desa santong ataupun kecamatan kayangan pada umumnya. Pada umumnya proses produksi dilakukan $1 x$ dalam seminggu, dengan bahan baku seperti pada tabel 1. Proses produksi sendiri dengan bahan baku 1 karung ubi, bisa memakan waktu hingga 4 hari. Proses produksi ini cukup lama, dikarenakan pemrosesan pada bagian mencincang ubi yang memakan waktu sekitar 3 hari, dan lebih kepada kegiatan sampingan, 
sehingga tidak terlalu diseriusi. Dan kegiatan oleh "tenaga kerja" ini sifatnya sukarela. Perusahaan Eri Sagruk tidak mempergunakan tenaga kerja khusus dalam proses produksinya, melainkan mengandalkan tenaga sendiri, dan bantuan dari para tetangga.

Berdasarkan data awal di atas, maka dapat dibuat perhitungan laba rugi versi Usaha Aisah, seperti yang terlihat pada tabel di bawah ini:

Tabel 2. Laba Rugi/Batch Produksi dari Penjualan Ubi Cincang Pedas Versi Usaha Aisah

\begin{tabular}{|l|r|}
\hline Keterangan & Rupiah \\
\hline $\begin{array}{l}\text { Penjualan 500 bks Ubi Cincang Tiap } \\
\text { Produksi (Produksi per bulan } 500 \times 4=2.000 \\
\text { bks) }\end{array}$ & Rp 2.000.000 \\
\hline HPP & (Rp 1.505.200) \\
\hline Laba Kotor & Rp 494.800 \\
\hline
\end{tabular}

Sumber: Data Primer (diolah)

2. Diskusi lanjutan,

Diskusi lanjutan ini dilakukan dengan memberikan kesempatan kepada tim pengabdian untuk menjelaskan ke Bapak Heri Sagruk tentang metode perhitungan harga pokok produksi dengan menggunakan pendekatan full costing. Beberapa hal yang belum masuk perhitungan dalam harga pokok, yang dijadikan sebagai penekanan, seperti biaya tenaga kerja langsung, dan biaya overhead pabrik yang pasti ada dalam setiap proses produksi, namun di dalam produksi ubi cincang pedas oleh Usaha Aisah ini tidak diturutsertakan dalam perhitungan biaya.

Sebagai inisiatif dari tim pengabdian, maka perhitungan biaya yang benar dilakukan, dengan memasukkan komponen-komponen biaya yang belum diperhitungkan dalam perhitungan harga pokok produk ubi cincang pedas. Berikut adalah beberapa perhitungan yang terkait dengan Biaya tenaga kerja langsung dan biaya penyusutan peralatan atau aset tetap lainnya.

\section{a. Biaya Tenaga Kerja Langsung}

Biaya tenaga kerja langsung adalah biaya yang dikeluarkan sebagai upah tenaga kerja yang langsung terlibat dalam proses produksi. UD Aisah 


\section{Jurnal ABDIMAS INDEPENDEN}

Vol. 2, No. 2, November 2021

tidak memasukkan komponen ini ke dalam perhitungan harga pokok produksi ubi cincang pedas. Dari hasil wawancara, pekerja yang membantu proses produksi tidak sepenuh hari bekerja, melainkan jika ada waktu senggang saja. Dengan demikian maka upah yang diberikan juga tidak perlu terlalu tinggi. Tim pengabdian mengasumsikan upah tenaga kerja langsung per hari (dengan asumsi tidak sepenuh hari membantu dalam hal proses produksi) adalah sebesar $\mathrm{Rp}$ $10.000,00 /$ hari, dengan proses pengerjaan tiap produksi/batch produksinya adalah selama 4 hari, maka total upah tenaga kerja langsung adalah sebesar $\mathrm{Rp} 40.000,00$. Jika dikalikan dengan jumlah produksi sebanyak 4 batch per bulan, maka total upah tenaga kerja adalah sebesar Rp 160.000.

b. Beban penyusutan Aset Tetap untuk Kegiatan Produksi

Berdasarkan hasil wawancara, beberapa aset tetap yang dipergunakan dalam proses produksi adalah sebagai berikut:

Tabel 3. Daftar Peralatan/Aset Tetap untuk Kegiatan Produksi

\begin{tabular}{|l|l|r|}
\hline No & Nama Peralatan/Aset Tetap Produksi & Harga Pokok (Rp) \\
\hline 1 & Pisau & 25.000 \\
\hline 2 & Talenan & 10.000 \\
\hline 3 & Ember & 25.000 \\
\hline 4 & Wajan & 100.000 \\
\hline 5 & Kompor & 250.000 \\
\hline 6 & Sutil & 20.000 \\
\hline 7 & Penyaringan & 25.000 \\
\hline
\end{tabular}

Sumber: Data Primer (diolah)

Dari daftar peralatan aset tetap tersebut, kemudian dihitung tarif penyusutan per bulan untuk masing-masing peralatan/aset tetap produksi, dengan mempergunakan metode garis lurus (Straigh Line Method). Ada pun rumus untuk menghitung tarif penyusutan per bulan adalah (Jusup, 2011):

Tarif Penyusutan: $\frac{\text { Harga Perolehan } A T-N S}{\text { Umur Ekonomis }}$ 
Dengan mempergunakan rumus perhitungan tarif penyusutan tersebut, maka disusunlah list tarif penyusutan pada tabel 4 berikut ini:

Tabel 4. Daftar Tarif Penyusutan Peralatan/Aset Tetap Produksi/Bulan

\begin{tabular}{|c|l|c|r|r|}
\hline NO & \multicolumn{1}{|c|}{ Aset Tetap } & $\begin{array}{c}\text { Umur } \\
\text { Ekonomis } \\
\text { (BIn) }\end{array}$ & $\begin{array}{c}\text { Harga } \\
\text { Perlehan }\end{array}$ & \multicolumn{1}{c|}{$\begin{array}{c}\text { Tarif } \\
\text { Penyusutan/Bulan }\end{array}$} \\
\hline 1 & Pisau & 6 & 25.000 & $4.166,67$ \\
\hline 2 & Talenan & 6 & 10.000 & $1.666,67$ \\
\hline 3 & Ember & 12 & 25.000 & $2.083,33$ \\
\hline 4 & Wajan & 36 & 100.000 & $2.777,78$ \\
\hline 5 & Kompor & 36 & 250.000 & $6.944,44$ \\
\hline 6 & Sutil & 12 & 20.000 & $1.666,67$ \\
\hline 7 & Penyaringan & 12 & 25.000 & $2.083,33$ \\
\hline & Total Penyusutan Per Bulan & & $21.388,89$ \\
\hline
\end{tabular}

Sumber: Data Primer (diolah)

Umur ekonomis adalah berdasarkan asumsi dari Tim Pengabdian, tentu dengan mengkonfirmasi Pak Heri Sagruk sebelumnya.

Dari tabel 4, dapat dilihat bahwa tarif penyusutan per bulan adalah sebesar Rp 21.388,89. Biaya penyusutan ini akan turut diperhitungkan sebagai beban overhead pabrik. Dengan telah diperhitungkannya Biaya Tenaga Kerja Langsung dan adanya tambahan atas biaya overhead pabrik, maka dapat diperhitungkan harga pokok produksi sebagai berikut:

Tabel 5: Harga Pokok Produk Ubi Cincang Pedas Dengan Mempergunakan Metode Full Costing

\begin{tabular}{|l|l|l|l|l|l|}
\hline No & \multicolumn{1}{|c|}{ Jenis Biaya } & Unit & $\begin{array}{c}\text { Harga } \\
\text { @ (Rp) }\end{array}$ & $\begin{array}{c}\text { Jumlah } \\
\text { (Rp) }\end{array}$ & Total (Rp) \\
\hline 1 & $\begin{array}{l}\text { Biaya Bahan Baku } \\
\text { (Ubi) } \\
\text { Total B. Bahan Baku }\end{array}$ & $4 \mathrm{krg}$ & 250.000 & 1.000 .000 & $\mathbf{1 . 0 0 0 . 0 0 0}$ \\
\hline 2 & $\begin{array}{l}\text { Biaya Tenaga Kerja } \\
\text { Langsung/minggu } \\
\text { B. TKL/Bulan (BKTL } \\
\text { per minggu 4) }\end{array}$ & 4 Org & 10.000 & 40.000 & \\
\hline 3 & $\begin{array}{l}\text { Biaya Overhead } \\
\text { Pabrik (BOP) 1 } \\
\text { karung per minggu } \\
\text { Bumbu-bumbu: } \\
\text { 1. Cabe Basah } \\
\text { 2. Bawang Putih }\end{array}$ & $11 \mathrm{Kg}$ & 15.000 & 15.000 \\
\hline
\end{tabular}




\section{Jurnal ABDIMAS INDEPENDEN}

Vol. 2, No. 2, November 2021

\begin{tabular}{|c|c|c|c|c|c|}
\hline No & Jenis Biaya & Unit & $\begin{array}{l}\text { Harga } \\
@(\text { Rp) }\end{array}$ & $\begin{array}{c}\text { Jumlah } \\
\text { (Rp) }\end{array}$ & Total (Rp) \\
\hline & 3. Cabe Kering & $0,25 \mathrm{Kg}$ & 20.000 & 5.000 & \\
\hline & 4. Penyedap & 0,5 Gram & 20.000 & 10.000 & \\
\hline & Rasa & $0,5 \mathrm{Kg}$ & 14.000 & 7.000 & \\
\hline & 5. Gula & $0,25 \mathrm{Kg}$ & 20.000 & 5.000 & \\
\hline & 6. Garam & $1 \mathrm{Pkt}$ & 2.000 & 2.000 & \\
\hline & 7. Kapur & & & & \\
\hline & Biaya Air & 1 hari & 300 & 300 & \\
\hline & Minyak Goreng & $1 \mathrm{Kg}$ & 12.000 & 12.000 & \\
\hline & Kemasan & 5 bks & 12.000 & 60.000 & \\
\hline & & & & 126.300 & \\
\hline & Biaya & & & 21.389 & \\
\hline & Penyusutan/bulan & & & & \\
\hline & Total BOP Per Minggu & & & 147.689 & \\
\hline & $\begin{array}{l}\text { Total BOP per bulan } \\
\text { (BOP/Minggu } \times 4 \text { ) }\end{array}$ & & & & 590.756 \\
\hline & $\begin{array}{l}\text { Harga Pokok } \\
\text { Produksi } \\
\text { HPP/Unit (2000 unit) }\end{array}$ & & & & $\begin{array}{r}1.750 .756 \\
875,38\end{array}$ \\
\hline
\end{tabular}

Sumber: Data Primer (diolah)

Berdasarkan Tabel 5, maka dapat dihitung laba kotor per bulan UD Aisah sebagai berikut:

Tabel 6. Laba Rugi/Batch Produksi dari Penjualan Ubi Cincang Pedas dengan Menggunakan Metode Full Costing

\begin{tabular}{|l|r|}
\hline \multicolumn{1}{|c|}{ Keterangan } & \multicolumn{1}{|c|}{ Rupiah } \\
\hline $\begin{array}{l}\text { Penjualan 500 bks Ubi Cincang Tiap Produksi } \\
\text { (Produksi per bulan 500 } \times 4=2.000 \mathrm{bks})\end{array}$ & $\mathrm{Rp} \mathrm{2.000.000}$ \\
\hline HPP & $(\operatorname{Rp~1.750.756)}$ \\
\hline Laba Kotor & $\operatorname{Rp~249.244}$ \\
\hline
\end{tabular}

Sumber: Data Primer (diolah)

Berdasarkan perhitungan harga pokok produksi dengan pendekatan full costing tersebut, maka keuntungan Pak Heri Sagruk per bulan dari usaha ubi cincang pedas adalah Rp 249.244.

\section{Pembahasan}

Kegiatan pengabdian pada masyarakat ini dilakukan untuk mengetahui perhitungan harga pokok produksi pada usaha ubi cincang 
pedas Usaha Aisah milik Bapak Heri Sagruk yang sudah dijalankan selama 5 tahun lamanya, namun selama ini Bapak Heri Sagruk tidak menggunakan metode apapun dalam perhitungan harga pokok produksinya. Setelah mengetahui perhitungan harga pokok produksi menurut yang selama ini dilakukan oleh Bapak Heri Sagruk, selanjutnya dilakukan perhitungan harga pokok dengan mempergunakan metode full costing.

Perhitungan harga pokok produksi tersebut difokuskan pada produk ubi cincang pedas. Perlu diketahui bahwa Usaha Aisah juga memproduksi cemilan keripik singkong dan kacang asin di samping memproduksi ubi cincang pedas. Bapak Heri Sagruk merasa terbantu, dalam hal menambah wawasan beliau dalam memperhitungkan harga pokok sebenarnya dari usaha yang selama ini beliau jalankan.

Sesuai dengan pembahasan pada sub bab sebelumnya, berdasarkan informasi yang disampaikan oleh Bapak Heri Sagruk mengenai harga pokok produksinya terhadap perbedaan antara praktik perhitungan harga pokok produksi yang selama ini beliau lakukan, dibandingkan dengan harga pokok produksi yang dihitung oleh tim pengabdian berdasarkan data yang dikumpulkan.

Perhitungan harga pokok produksi pembuatan Ubi Cincang Pedas menurut Bapak Eri Sagruk seperti yang terlihat pada tabel 1, maka harga pokok produksi pembuatan ubi cincang pedas per bungkus kecilnya adalah seharga Rp 752,6, dengan harga jual Rp 1.000 per bungkusnya, atau per bulan dengan produksi diasumsikan $4 x$ dalam sebulan dengan menghasilkan 2.000 bungkus akan menghasilkan laba kotor sebesar Rp 494.800,00.

Laba kotor tersebut berbeda dengan perhitungan yang dihasilkan oleh tim pengabdian, dengan mengkoreksi perhitungan Bapak Heri Sagruk terutama pada penambahan komponen biaya yang belum diperhitungkan dalam harga pokok produksi ubi cincang pedas, yaitu biaya tenaga kerja langsung dan salah satu komponen BOP, yaitu pembebanan tarif penyusutan atas peralatan atau aset tetap yang dipergunakan dalam proses produksi. 
Berdasarkan hasil perhitungan dari tim pengabdian, seperti yang dilihat pada tabel 5, maka biaya produksi dengan mempergunakan metode full costing adalah Rp 875,38 per bungkusnya, atau atau per bulan dengan produksi diasumsikan $4 x$ dalam sebulan dengan menghasilkan 2.000 bungkus akan menghasilkan laba kotor sebesar Rp 249.244,00.

\section{KESIMPULAN DAN SARAN}

\section{Kesimpulan}

Kegiatan pengabdian ini berjalan dengan lancar dan semoga berhasil memberikan pemahaman tentang perhitungan harga pokok produksi Bapak Heri Sagruk, bahwa penentuan harga pokok produksi ubi cincang pedas yang dilakukan selama ini masih kurang benar, karena perhtiungannya tidak berdasarkan pada metode yang telah disepakati dalam akuntansi biaya yaitu metode full costing ataupun variable costing. Kegiatan pengabdian dilaksanakan pada hari Sabtu, 10 Oktober 2020 dari pukul 09.00 WITA sampai dengan selesai. Kegiatan pengabdian dilakukan dengan metode diskusi dua arah antara Bapak Heri Sagruk dengan Tim Pengabdian. Dari kegiatan pengabdian ini memberikan kesimpulan bahwa terdapat selisih harga pokok menurut Bapak Heri Sagruk dengan perhitungan versi Tim Pengabdian, dan demikian juga mengakibatkan adanya perbedaan hasil laba kotor per bulannya.

\section{Saran}

Berdasarkan temuan/hasil dari kegiatan pengabdian yang menunjukkan bahwa Bapak Heri Sagruk masih keliru dalam menentukan harga pokok produk ubi cincang pedas, maka disarankan Bapak Heri Sagruk untuk menerapkan perhitungan harga pokok produk dengan pendekatan full costing, agar dapat mengevaluasi penentuan harga, dan mengetahui keuntungan yang sebenarnya yang dihasilkan dari produksi ubi. 


\section{Daftar Pustaka}

Mulyadi. 2012. Akuntansi Biaya. Yogyakarta: BPFE

Jusup, Al. Haryono.2011.Dasar-Dasar Akuntansi Jilid 2 Edisi 7. Yogyakarta: STIE YKPN. 


\section{Jurnal ABDIMAS INDEPENDEN}

Vol. 2, No. 2, November 2021

Lampiran

Gambar 1. Proses Membersihkan Kulit Ubi

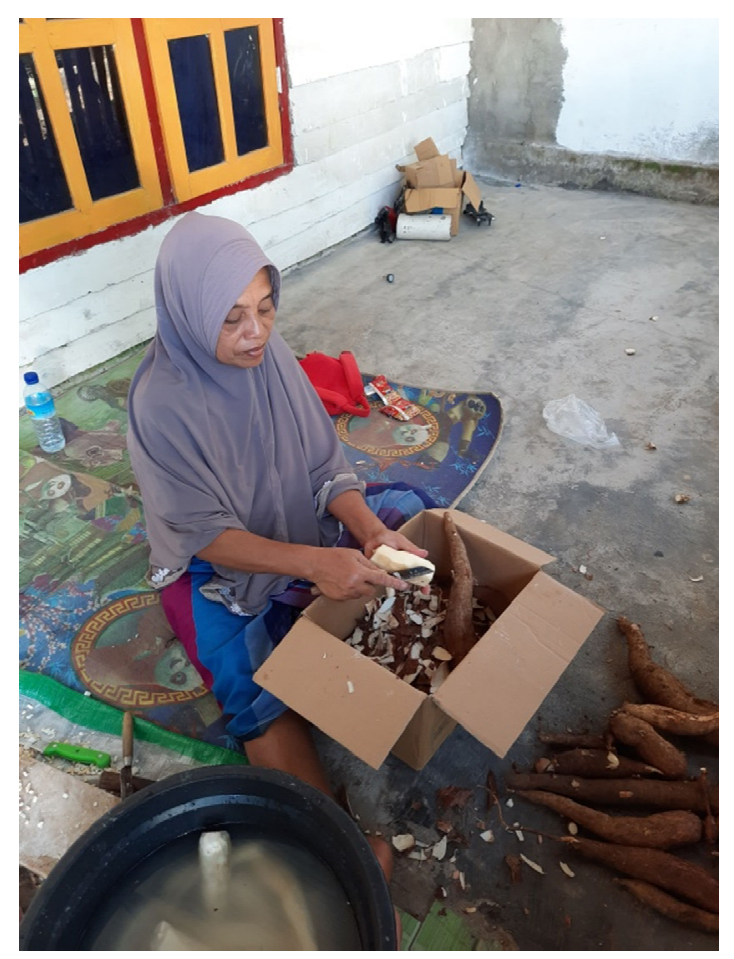

Gambar 2. Proses Mencincang Ubi Menjadi ukuran Dadu Kecil

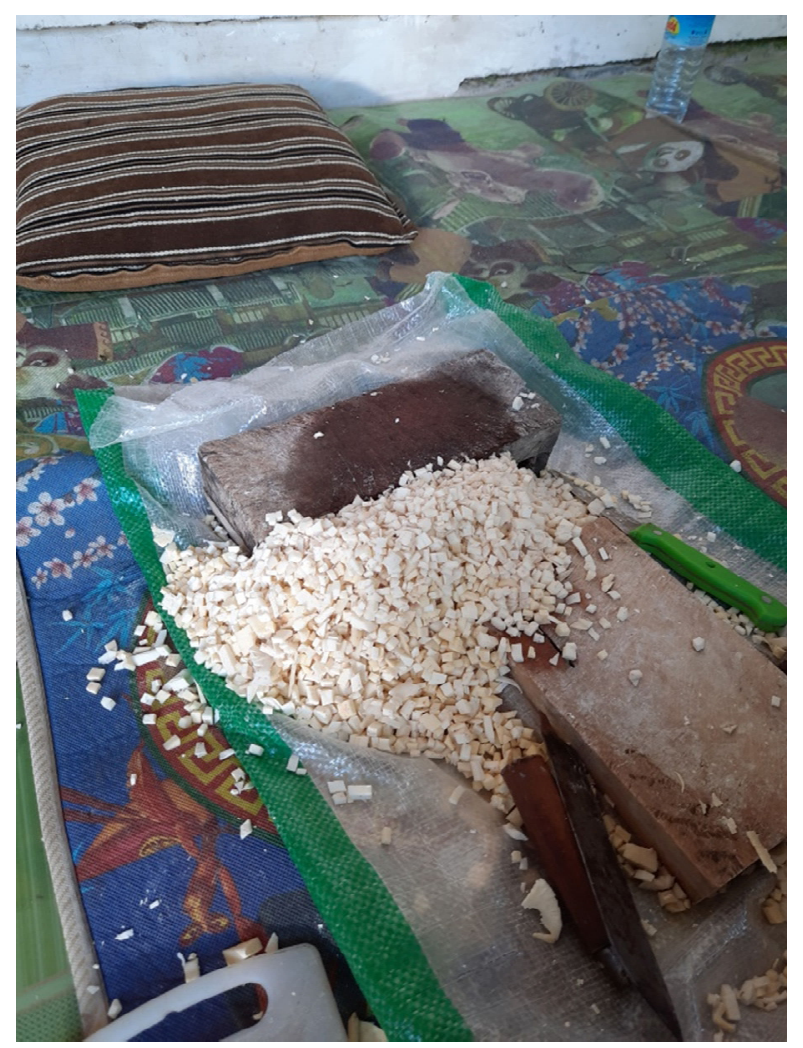




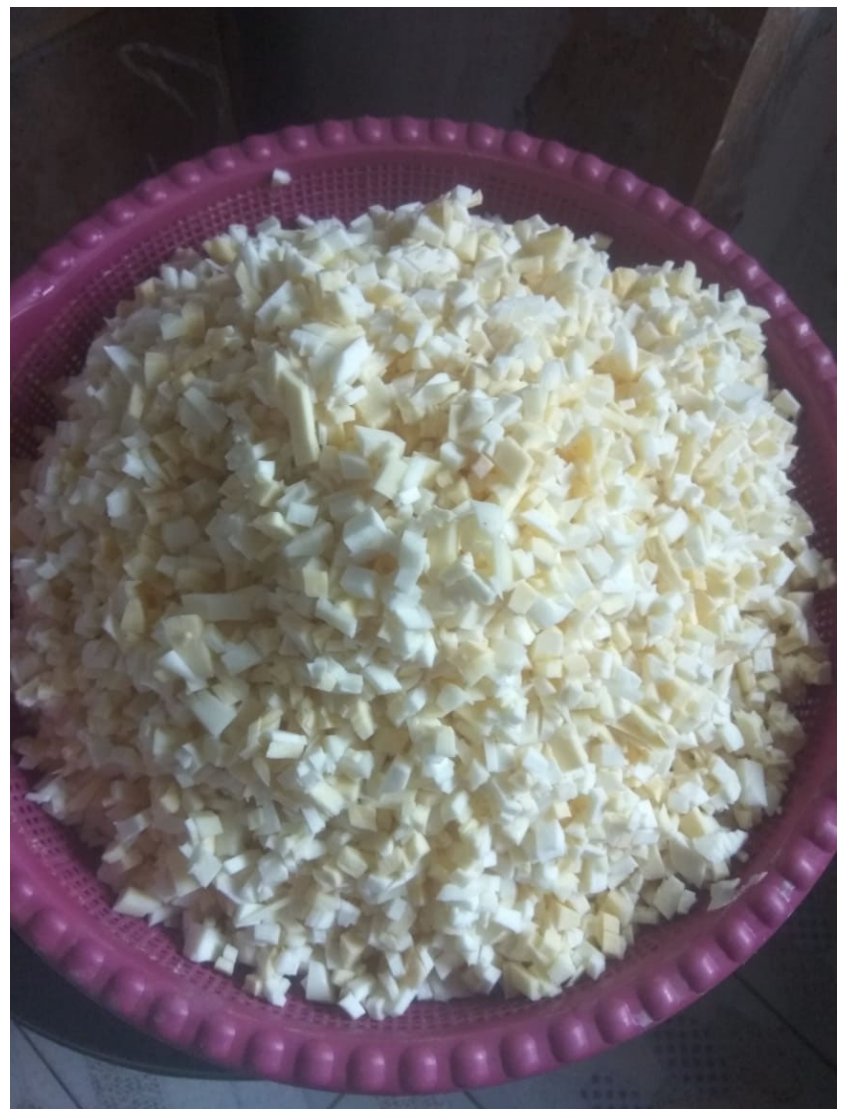

Gambar 3. Proses Menggoreng Ubi Cincang

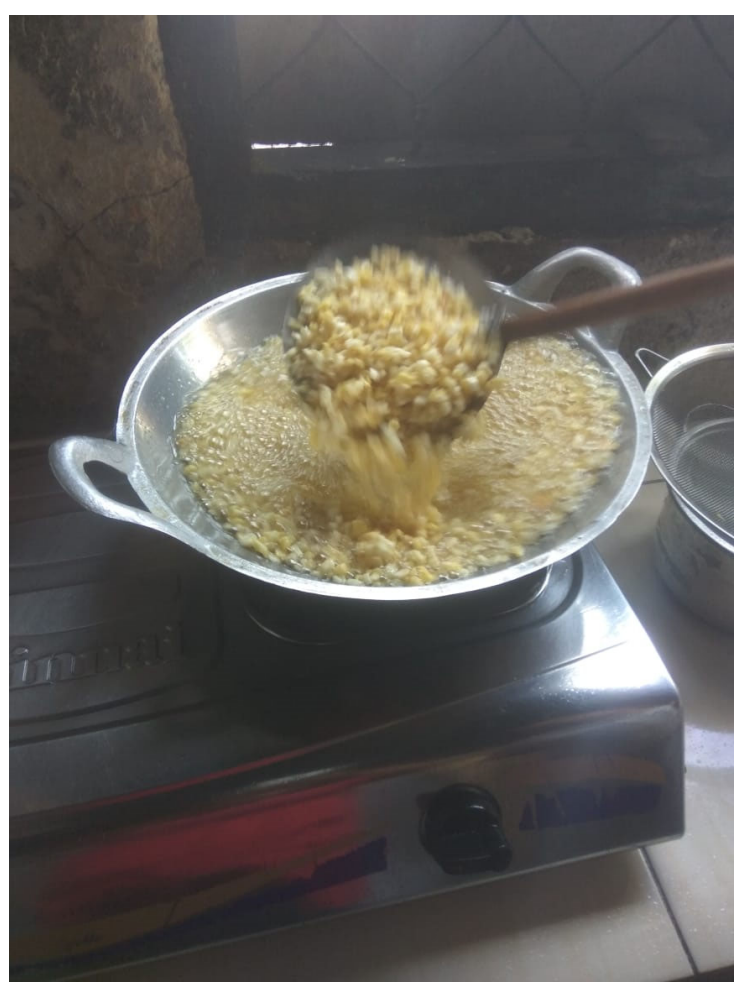

Gambar 4. Proses Pengemasan Ubi Cincang Pedas 


\section{Jurnal ABDIMAS INDEPENDEN}

Vol. 2, No. 2, November 2021

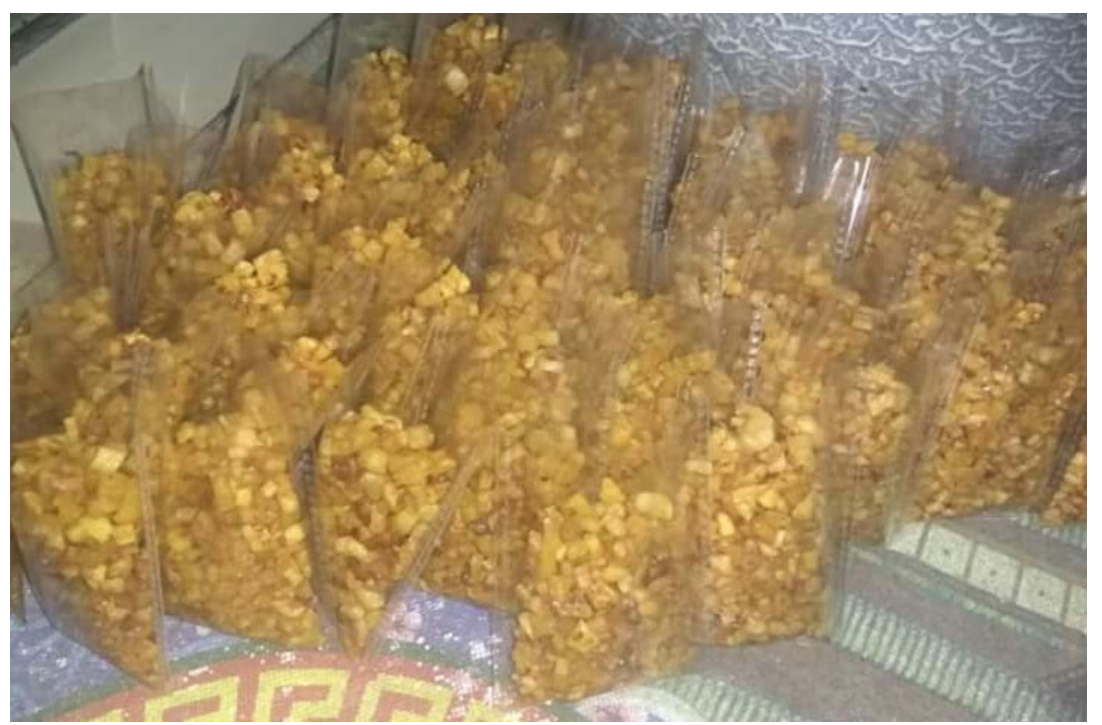

Gambar 5. Ubi Cincang yang Telah Dikemas
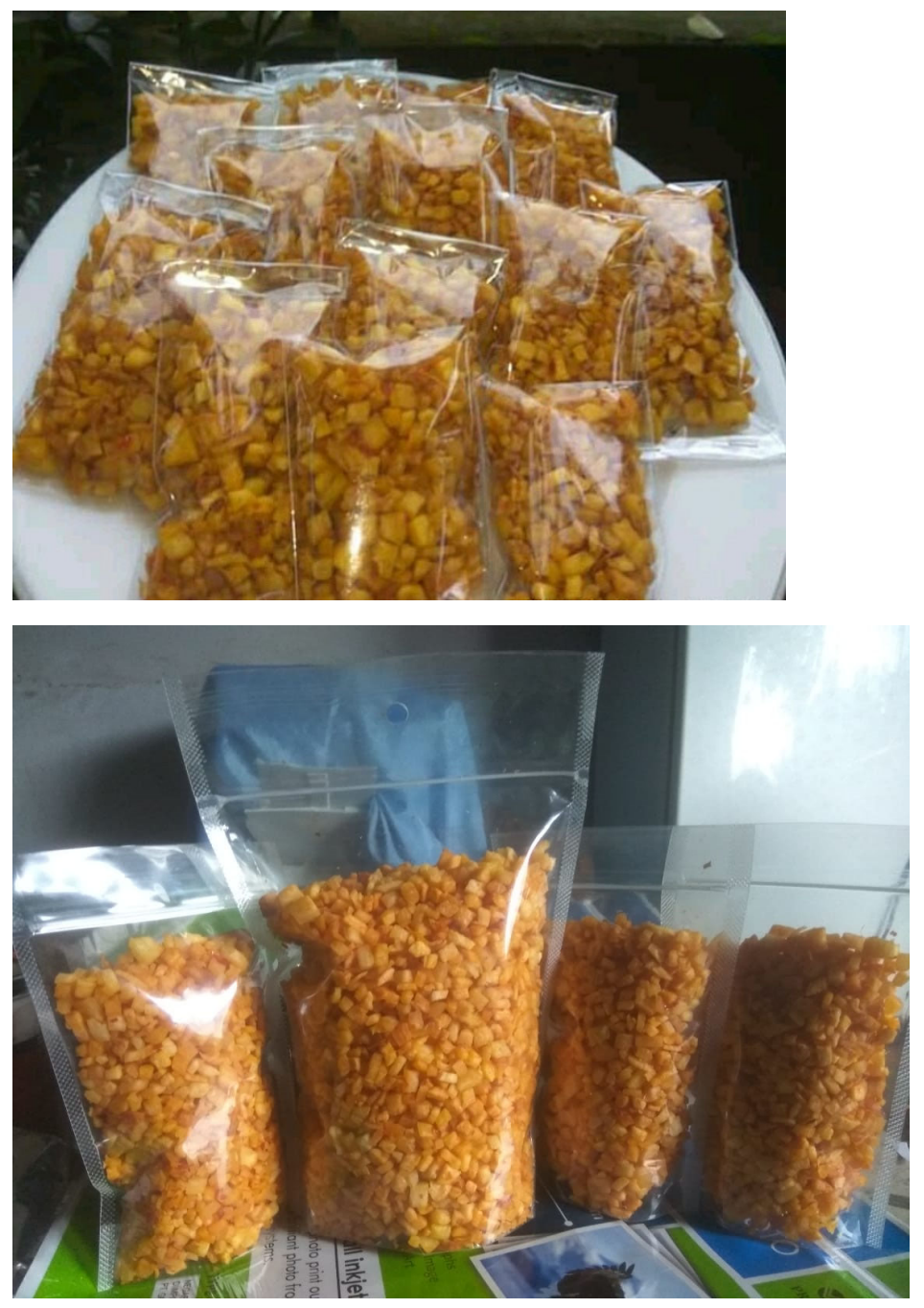
Gambar 6. Sesi Wawancara Proses Pembuatan Ubi Cincang Pedas dengan Bapak Heri Sagruk

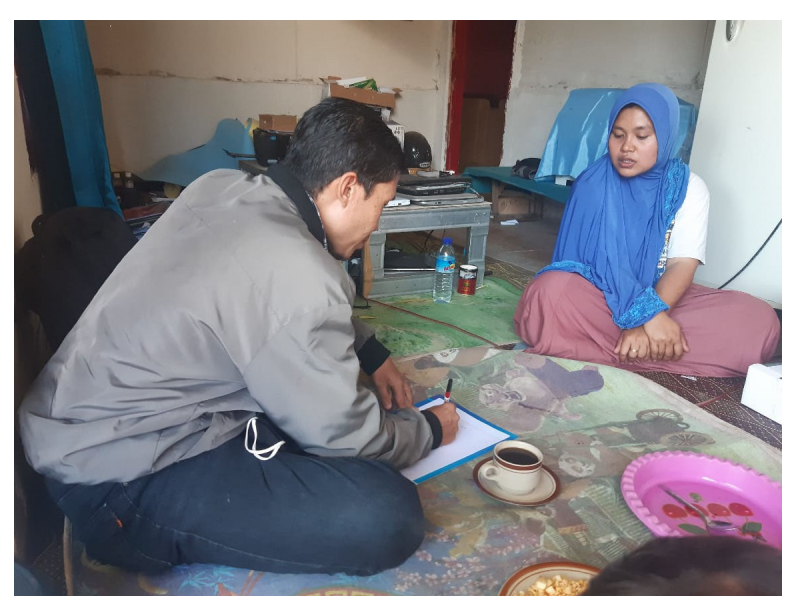

Gambar 7. Sesi Diskusi dengan antara Bapak Heri Sagruk dan Tim Pengabdian

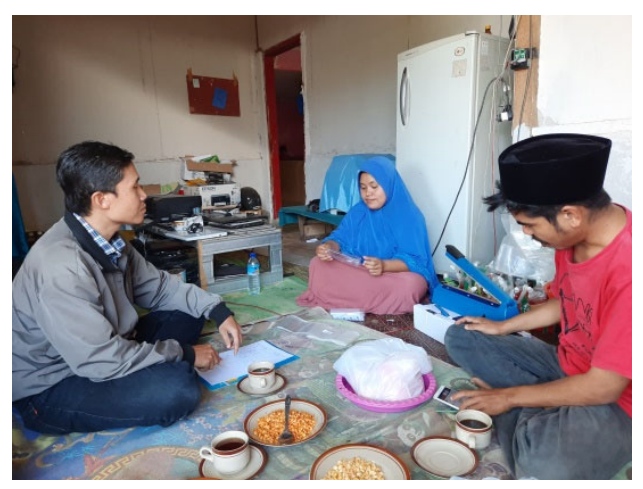

